\title{
\begin{tabular}{l|l|l} 
Jurnal Eksplorasi Akuntansi & e-ISSN : 2656-3649 (Online) \\
Vol. 3, No 1, Februari 2021, Hal 82-97 & http://jea.ppj.unp.ac.id/index.php/jea
\end{tabular}
}

\section{Pengaruh Audit Tenure dan Auditor Switching terhadap Kualitas Audit dengan Financial Distress sebagai Pemoderasi}

\author{
Dede Elevendra ${ }^{1}$, Nayang Helma Yunita ${ }^{2}$ \\ ${ }^{1,2}$ Universitas Negeri Padang, Padang, Indonesia \\ *Korespondensi: dedeelevendra11@gmail.com
}

\begin{abstract}
The purpose of this papers was to determine the effect of audit tenure and auditor switching on audit quality with financial distress as a moderating variable. The analysis of this research used logistic regression analysis. The sample consists of companies listed on the Indonesia Stock Exchange (BEI) for the current year (2015-2019). The results showed that audit tenure and auditor switching had no effect on audit quality and financial distress was unable to moderate the effect of audit tenure and auditor switching on audit quality.
\end{abstract}

Keywords: Audit Quality; Audit Tenure; Auditor Switching; Financial Distress

\section{How to cite}

Elevendra, D., \& Yunita, N. H. (2019). Pengaruh Audit Tenure dan Auditor Switching Terhadap Kualitas Audit dengan Financial Distress Sebagai Pemoderasi. Jurnal Eksplorasi Akuntansi, 3 (1), 82-97.

\section{PENDAHULUAN}

Laporan keuangan merupakan salah satu perwujudan dari tanggung jawab manajemen terhadap pemangku kepentingan, terkhususnya bagi penanam modal. Informasi yang tercantum didalam laporan keuangan bisa dipakai sebagai landasan dalam penetuan kebijakan oleh pihak-pihak yang berkepentingan. Setidaknya laporan keuangan perusahaan wajib memenuhi 2 ciri, yaitu relevan serta reliabel supaya bisa memberikan cerminan serta data prospek perseroan yang dibutuhkan oleh pihak dalam perusahaan dan luar perusahaan untuk tujuan penetapan kebijakan perusahaan (Lestari, et al., 2019).

Laporan keuangan disebut relevan ketika laporan keuangan tersebut dapat menolong pengguna laporan tersebut dalam melakukan penilaian atas kegiatan bisnis yang telah dilakukan serta demi pengambilan kebijakan untuk masa mendatang (Lestari, et al., 2019). Sedangkan laporan keuangan disebut reliabel ketika informasi yang termuat pada laporan keuangan tersebut terjamin dan salah saji yang material tidak ditemukan, selain itu pengguna laporan tersebut dapat mengandalkannya sebagai penyajian yang disusun secara jujur sesuai dengan yang seharusnya (Lestari, et al., 2019). Guna meningkatkan keterpercayaan pemangku kepentingan terhadap relevansi dan keandalan laporan keuangan maka diperlukan pihak yang independent dan juga netral dalam melakukan audit pada laporan keuangan.

Salah satu alat guna meminimalisir kesalahan dan kecurangan yang terjadi dalam laporan keuangan yang nantinya akan dipakai oleh pemangku kepentingan untuk urusan pengambilan keputusan adalah audit, pihak ketiga dibutuhkan untuk melakukan audit agar dapat menyatakan pendapatnya tentang laporan yang telah dibuat oleh manajemen agar dapat 
dipercaya. Sejalan dengan hal tersebut, teori agensi juga menjelaskan pentingnya jasa independen dari pihak ketiga yang netral sebagai pemecahan masalah dari konflik kepentingan principal dengan agen.

SPAP telah mengeluarkan aturan harus dijadikan pedoman bagi seorang akuntan publik dalam melakukan audit dengan tujuan agar dihasilkan kualitas audit yang terjaga. Kualitas audit dapat diartikan sebagai peluang bahwa terdapat kesalahan yang material pada laporan keuangan dan akuntan publik bermaksud untuk mencari dan membuat laporan mengenai kesalahan yang material tersebut (DeAngelo, 1981). Lee, et al. (1999) mengartikan kualitas audit sebagai peluang diamana opini wajar tanpa pengecualian tidak akan diberikan auditor ketika laporan keuangan berisikan kesalahan yang material. Sedangkan menurut Kurnia, et al., (2014) kualitas audit bisa diartikan sebagai peluang bagi akuntan publik dalam mendapati dan mengungkapkan mengenai terjadinya pelanggaran dalam catatan keuangan kliennya. Kualitas audit ialah kapabilitas seorang auditor dalam mendapati dan mengungkapkan mengenai adanya suatu kekeliruan dan penyelewengan yang terdapat pada praktik akuntansi kliennya. Kualitas audit dapat diartikan sebagai fungsi independensi dan kompetensi bagi auditor terhadap manajemen perseroan agar dapat melaporkan pelanggaran maupun penyelewengan akuntansi (Wisanggeni \& Ghozali, 2017).

Demi menjaga amanat dari pemakai laporan keuangan atas independensi auditor, departemen keuangan pada tahun 2015, dikeluarkan PP No. 20/2015 mengenai praktik akuntan publik. Dimana pada PP No. 20/2015 pasal 11 ayat (1) menjelaskan bahwa KAP tidak lagi dibatasi dalam memberikan jasa audit pada auditee yang sama. Dimana yang dibatasi hanya auditor, yaitu selama 5 tahun buku secara berturut-turut. Dengan ditambahnya masa perikatan bagi akuntan publik dalam melakukan audit dengan klien audit yang sama selama berturut-turut akan membuat audit tenure menjadi semakin panjang. Dengan adanya peraturan tahun 2015 ini semakin memperpanjang audit tenure yang terjadi antara auditor dengan klien audit, panjangnya waktu kontrak auditor dengan kliennya dapat mempengaruhi kualitas audit. Rentang waktu perikatan ini sering disebut dengan audit tenure.

Audit tenure merupakan panjangnya masa perikatan yang terjadi antara akuntan publik dari KAP dengan klien audit (Werastuti, 2013). Kualitas audit bisa dipengaruhi oleh audit tenure, hal ini dapat terlihat dari panjangnya masa perikatan auditor dengan auditee. Semakin lama audit tenure yang terjadi dapat dipandang sebagai tambahan penerimaan bagi auditor, namun semakin panjang tenure yang terjadi dapat mengakibatkan terjalinnya ikatan emosional antara auditor dengan klien audit yang bisa mengarah pada penurunan independensi yang akan menurunkan kualitas audit. Permasalahan mengenai lamanya auditor melakukan audit pada klien yang sama dapat diatasai dengan adanya auditor switching. Auditor switching dapat dijelaskan sebagai bergantinya auditor ataupun KAP oleh klien audit. salah satu faktor dari sisi klien yang menyebabkan terjadinya pergantian auditor adalah adanya keadaan kesulitan keuangan.

Schwartz \& Menon (1985) dalam Pradnyaniti \& Suardikha (2019) menyatakan bahwa terdapat pengaruh yang signifikan bagi perusahaan yang mengalami kesulitan keuangan untuk melakukan pergantian auditor atau KAP. Financial distress mengakibatkan perusahaan memiliki potensi untuk bangkrut yang menandakan bahwa kemampuan perusahaan untuk membayarkan fee audit yang dibebankan menjadi menurun, sehingga akan mengakibatkan pada putusnya kontrak yang terjadi antara manajemen dengan auditor ataupun KAP.

Motivasi penulis untuk melakukan penelitian ini karena masih terdapat banyak perdebatan mengenai bagaimana pengaruh antara auditor switching dan audit tenure terhadap kualitas audit. Jayanti \& Widhiyani. (2014) mendapati bahwa auditor switching berpengaruh akan membuat independensi auditor tetap terjaga. Penelitian Omri \& Abdennebi, (2014) menemukan bahwa rotasi audit memiliki dampak negatif pada kualitas audit, artinya dengan adanya pergantian auditor membuat penurunan pada kualitas audit. Dalam penelitian ini 
penulis lebih condong pada pendapat bahwa audit tenure yang panjang akan membuat kualitas audit menurun, karena auditor bisa kehilangan independensinya jika terjalin perikatan yang cukup lama dengan klien audit yang sama.

\section{REVIU LITERATUR DAN HIPOTESIS \\ Teori Keagenan (AgencyTheory)}

Teori agensi atau keagenan melaporkan diperlukannya jasa independen dari pihak ketiga yang netral atau auditor bisa dipaparkan dengan teori keagenan (Agency Theory) sebagai dasarnya, yaitu ikatan principal (owner) dengan pihak agen (manajemen) (Tandiontong, 2015). Pertumbuhan perusahaan yang semakin pesat akan menimbulkan konflik antara principal (penanam modal) dengan pihak manajemen perusahaan yang berperan sebagai agen dalam perusahaan.

Anggapan kalau manajemen yang bertugas untuk sebagai agen pada perusahaan akan senantiasa memaksimalkan keuntungan perusahaan tidak senantiasa terpenuhi. Pihak pengelola mempunyai kepentingan individu yang berlawanan terhadap kepentingan pemilik perseroan sehingga memunculkan kasus yang dikenal dengan permasalahan agensi, akibat terdapatnya kesenjangan informasi. Adanya pihak independent yang berperan sebagai penengah atau pihak yang netral akan membantu dalam mengurangi permasalahan keagenan yang terjadi. Pihak penengah ini dikenal dengan auditor eksternal (Tandiontong, 2015).

\section{Teori Sinyal (Signalling Theory)}

Jama'an (2008) dalam Pradnyaniti \& Suardikha (2019) signalling theory menyatakan bagaimana seharusnya sinyal diberikan oleh perusahaan terhadap pembaca laporan keuangan. Sinyal ini dapat berbentuk pengetahuan mengenai apa saja yang telah dikerjakan manajemen dalam melaksanakan kepentingan pemilik. Sinyal juga bisa berbentuk promosi tentang bagaiman perseroan tersebut lebih unggul dari perseroan lain. Teori sinyal menemukan bahwa sinyal diberikan oleh pengelola perusahaan demi meminimalisir kesenjangan informasi. Melalui laporan keuangan pengelola perusahaan memberitahukan bahwa perusahaan memakai kebijakan akuntansi konservatisme untuk mendapatkan laba yang lebih dapat dipercaya karena prinsip ini mencegah perseroan untuk melaksanakan kegiatan menggelembungkan laba dan menolong pemakai laporan akuntansi dengan menampilkan laba dan aktiva yang tidak lebih saji.

\section{Audit Tenure}

Audit tenure ialah lamanya kontrak yang telah terjadi dalam hubungan auditor dari KAP dengan auditee yang sama dalam jangka waktu yang panjang (Werastuti, 2013). Jangka waktu perikatan klien audit dengan auditor yang sama dapat memengaruhi kualitas audit. Panjangnya audit tenure yang terjadi dapat dihitung sebagai tambahan penghasilan bagi auditor, namun tenure yang panjang bisa memicu untuk terjalinnya ikatan emosional antara auditor dengan klien auditnya, hal ini nantinya akan mengubah kualitas audit (Lee \& Sukartha, 2017). Dengan diterapkannya peraturan dari pemerintah terkait panjangnya masa kontrak atau tenure menjadi dilema bagi perusahaan, perusahaan mengalami masalah dalam pengambilan keputusan untuk melakukan pergantian auditor dengan cara merekrut auditor baru atau untuk mempertahankan dan melanjutkan pekerjaan dengan auditor lama (Aisyah, et al., 2015).

\section{Auditor Switching}

Auditor switching dapat diartikan sebagai pertukaran akuntan public yang dilaksanakan oleh manajemen perusahaan. Pertukaran auditor dilaksanakan karena jika terjadi penugasan audit dalam kurun waktu yang panjang dengan pihak klien akan membuat penurunan pada prinsip 
independensi seorang auditor, karena antara auditor dengan klien audit akan terjalin hubungan emosional yang akan menimbulkan masalah terkait peningkatan komitmen yang menghasilkan keputusan yang buruk dari seorang auditor. Pada 2015 dikeluarkan PP No. 20/2015 pasal 11 ayat (1) yang menyebutkan bahwa tidak ada lagi batasan bagi KAP dalam melaksanakan audit pada perusahaan yang sama. Pembatasan hanya ditujukan untuk auditor, dimana auditor hanya boleh melakukan audit 5 tahun berturut-turut pada perusahaan yang sama.

\section{Financial Distress}

Financial distress merupakan situasi dimana suatu unit usaha tengah berada dalam keadaan kesulitan keuangan. Almilia (dalam Jayanti \& Widhiyani, 2014) menjelaskan bahwa kesulitan keuangan sebagai suatu kondisi dimana hasil aktivitas ekonomi entitas tidak lagi cukup dalam pemenuhan kewajiban perusahaan atau disebut juga insolven. Ketika perusahaan tidak lagi dapat mengatasi permasalahan keuangan hal ini akan mengarah pada kepailitan, yang akan merugikan penanam modal, pemberi kredit, manajer, pemasok. Dari sudut pandang ekonomi perusahaan sepeti ini telah mengalami kegagalan.

\section{Kualitas Audit}

DeAngelo, (1981) memberikan penjelasan mengenai kualitas audit adalah kemungkinan gabungan dari kapabilitas auditor dalam menjumpai adanya pelanggaran pada laporan keuangan klien seta kesudian mereka dalam menghentikan pelanggaran ini. Tandiontong, (2015) mengartikan kualitas audit adalah kemungkinan seorang akuntan publik dalam menjumpai dan memberitakan suatu kesalahan dan penyelewengan yang terdapat pada praktik akuntansi klien.

\section{Pengaruh Audit Tenure Terhadap Kualitas Audit}

Dalam hubungan keagenan, terdapat kontrak yang terjadi antara principal dan agen. Agen diharuskan memberikan jasa kepada principal melalui kontrak tersebut. Akibat dari pendelegasian wewenang dari principal kepada agennya membuat agen memiliki akses dalam pengambilan keputusan. Namun, kepentingan kedua belah pihak tidak selalu sepemikiran sehingga akan menimbulkan masalah kepentingan bagi keduanya (Lee \& Sukartha, 2017). Auditor yang tadinya dipilih oleh pengelola perusahaan akan mendapat berbagai permasalahan ketika berhadapan dengan berbagai keinginan pada keagenan auditor. Tujuan manajemen menunjuk auditor agar melakukan pemeriksaan untuk kebutuhan principal, di sisi lain manajemen juga harus menanggung biaya audit. Permasalahan kelembagaan yang dialami auditor akan membuat auditor menjadi ketergantungan terhadap kliennya. (Lee dan Sukartha, 2017).

Perikatan akuntan publik dengan auditee seharusnya dapat meningkatkan kualitas audit. Wisanggeni \& Ghozali, (2017) mendapati bahwa lamanya audit tenure yang terjadi akan memiliki pengaruh negative terhadap kualtas audit, artinya semakin panjang audit tenure yang terjadi akan berimplikasi pada rendahnya kualitas audit yang dihasilkan. Sejalan dengan Wisanggeni \& Ghozali, Ball, et al. (2015) juga mendapati bahwa hubungan mitra audit yang lebih lama dengan manajemen senior dapat mengurangi kualitas audit melalui penurunan independensi audit. Berdasarkan pemaparan tersebut hipotesis dapat dirumuskan sebagai berikut:

H1: Audit tenure memiliki pengaruh negatif terhadap kualitas audit

\section{Pengaruh Auditor Switching Terhadap Kualitas Audit}

Auditor switching atau pertukaran auditor atau KAP dapat terjadi karena manajemen perusahaan atau auditor itu sendiri. Pemerintah melalui PP No. 20/2015 mengenai praktik 
akuntan publik. Dimana pada PP No. 20/2015 pasal 11 ayat (1) dijelaskan bahwa tidak ada lagi batasan bagi KAP untuk melakukan perikatan dengan klien, pembatasan hanya ditujukan bagi auditor, yaitu selama 5 tahun buku secara berturut-turut. Berdasarkan teori sinyal adanya pergantian auditor merupakan berita yang kurang baik bagi investor dan perusahan (Pradnyaniti \& Suardikha, 2019). Hal ini terjadi karena dengan adanya pergantian auditor dianggap dapat menurunkan kualitas audit karena dengan bergantinya auditor akan menyebabkan keterlambatan pelaporan yang akan berimbas pada buruknya kualitas audit yang dihasilkan.

Hal ini berlawanan dengan yang ditemukan oleh Jayanti \& Widhiyani, (2014) yang menemukan bahwa antara pergantian auditor dengan kualitas audit memiliki hubungan yang positif. Hubungan positif ini berarti dengan dengan dilakukannya pergantian auditor, akan menjaga independensi si auditor karena pendeknya kontrak yang terjadi antara auditor dengan klien audit yang akan meningkatkan kualitas audit. Omri \& Abdennebi, (2014) menemukan bahwa rotasi audit memiliki dampak negatif pada kualitas audit. Hal ini berarti pergantian auditor yang dilakukan akan membuat menurunkan kualitas audit. Berdasarkan pemaparan tersebut hipotesis penelitian dapat dirumuskan sebagai berikut:

H2: Auditor switching memiliki pengaruh positif terhadap kualitas audit

\section{Financial Distress Dalam Memoderasi Pengaruh Audit Tenure Terhadap Kualitas Audit}

Financial distress ialah keadaan dimana perusahaan berada dalam posisi kesulitan keuangan, sehingga ditakutkan akan mengarah pada kebangkrutan di kemudian hari. Ketika mengalami kondisi kebangkrutan perusahaan tidak lagi mampu untuk melaksanakan kewajibannya. Perusahaan yang berada diambang kebangkrutan cenderung untuk melakukan pergantian auditornya. Perpindahan auditor ini akan berakibat pada semakin pendeknya perikatan klien dengan auditornya.

Berdasarkan teori sinyal akan terdapat sinyal buruk bagi investor ketika perusahaan tengah mengalami keuslitan keuangan. Schwartz \& Menon (1985) dalam Pradnyaniti \& Suardikha (2019) mnemukan bahwa kondisi kesulitan keuangan akan mempengaruhi perushaan yang terancam bangkrut untuk berganti auditor. Financial distress akan mengindikasikan bahwa kemampuan financial perseroan semakin menurununtuk dapat menanggung biaya audit yang dibebankan oleh auditor, sehingga dapat mengakibatkan putusnya hubungan antara pengelola perusahaan dengan auditor. Semakin tinggi audit tenure maka auditor akan makin bergantung pada kliennya, hal ini akan membuat independensinya terganggu sehingga menurunkan kualitas auditnya. Hasil penelitian Jayanti \& Widhiyani (2014), menemukan bahwa financial distress memiliki pengaruh negatif terhadap kualitas audit. Dari pemaparan diatas, maka hipotesis penelitian dapat dirumuskan sebagai berikut:

H3: Financial distress memperkuat hubungan audit tenur terhadap kualitas audit

\section{Financial Distress Dalam Memoderasi Pengaruh Auditor Switching Terhadap Kualitas Audit}

Ketika terjadi kebangkrutan perusahaan tidak lagi mampu dalam pemenuhan kewajibannya. Perusahaan yang berada diambang kebangkrutan lebih cenderung untuk melakukan pergantian auditor. Masalah keagenan auditor berasal dari sistem kelembagaan yang terjadi antara auditor dengan manajemen (Wibowo \& Rossieta, 2009). Auditor ditunjuk oleh agen perusahaan demi melakukan audit demi keperluan prinsipal. Di sisi lain, manajemen harus menanggung dan mengeluarkan biaya untuk jasa audit. Dalam kondisi kesulitan keuangan pihak manajemen tidak lagi sanggup membayar auditor sehingga perikatan antara manajemen dan auditor menjadi terputus. 
Berdasarkan teori signal yang menyatakan ketika terjadi financial distress, hal tersebut akan menjadi sinyal buruk untuk investor, Schwartz \& Menon (1985) dalam Pradnyaniti \& Suardikha (2019) menyatakan bahwa financial distress memiliki pengaruh yang signifikan terhadap bagi perusahaan yang mengalami masalah keuangan untuk berganti auditor. Chadegni, et al. (2011) mendapati, guna menurunkan fee audit karena kesulitan keuangan perusahaan akan melakukan pergantian auditor. Penemuan ini didukung oleh penelitian Jayanti \& Widhiyani, (2014) yang menemukan bahwa kesulitan keuangan dapat melemahkan ikatan antara pergantian auditor terhadap kualitas audit, hal ini dikarenakan dengan adanya kondisi kesulitan keuangan akan mendorong perusahaan dalam menemukan KAP baru sebagai pengganti yang memiliki biaya audit yang lebih murah, dengan pemahaman dan pengalaman yang minim dari KAP sebelumnya akan berdampak pada menurunnya kualitas audit. Jayanti \& Widhiyani (2014) menemukan bahwa financial distress berpengaruh negatif bagi kualitas audit. Dari pemaparan, maka perumusan hipotesis penelitian ini sebagai berikut: H4: Financial distress memperlemah hubungan auditor switching terhadap kualitas audit

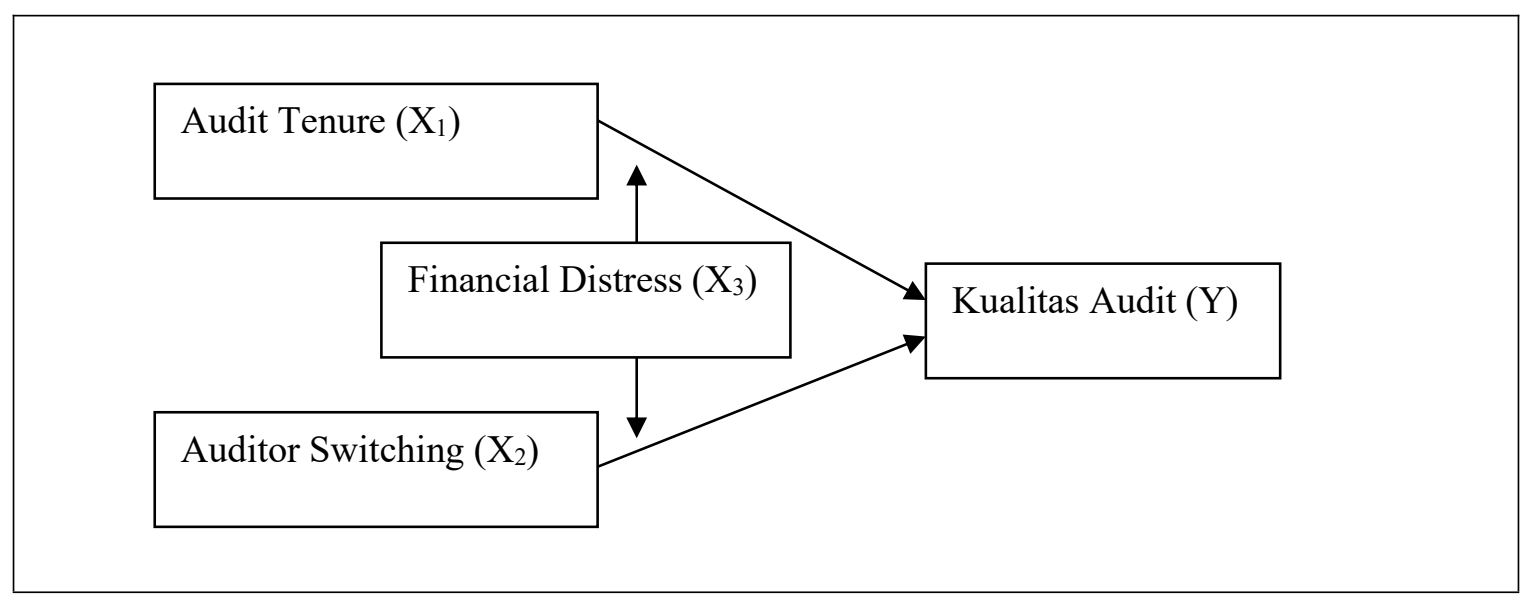

Gambar 1. Kerangka Konseptual

\section{METODE PENELITIAN}

Penelitian ini adalah penelitian kuantitatif, yaitu penelitian ini menekankan pada menguji teori melalui pengukuran variabel penelitian menggunakan angka dan menganalisis data sekunder menggunakan prosedur statistik, atau yang digunakan berupa angka-angka.

\section{Populasi dan sampel}

Tabel 1

\section{Kriteria Pengambilan Sampel}

\begin{tabular}{lr} 
Keterangan & Jumlah \\
\hline Perusahaan manufaktur yang melakukan pencatatan di Bursa & 158 \\
Efek Indonesia tahun 2014-2019 & $(85)$ \\
\hline $\begin{array}{l}\text { Perusahaan sampel yang datanya tidak lengkap terkait dengan } \\
\text { variabel penelitian }\end{array}$ & 74 \\
\hline Total perusahaan yang dapat dimasukkan sebagai sampel & 5 \\
\hline Tahun pengamatan (tahun) & 370
\end{tabular}

Populasi yang digunakan dalam penelitian ini adalah perusahaan manufaktur yang terdaftar di laman bursa efek Indonesia dlam kurun waktu 2015-2019. Sampel yang didapat 
dengan cara eliminasi dengan menggunakan teknik purposive sampling adalah sebanyak 74 sampel dengan dengan jumlah pengamatan sebanyak 370 pengamatan.

\section{Jenis, Sumber dan Teknik Pengumpulan Data}

Penelitian ini menggunakan jenis data skunder berupa data kuantitatif dari laporan keuangan tahunan (annual report), pada perusahaan sector manufaktur yang terdaftar di Bursa Efek Indonesia (BEI) periode 2015-2019. Sumber data skunder yang digunakan diperoleh dari situs resmi Bursa Efek Indonesia (BEI) yaitu www.idx.co.id dan website resmi masingmasing perusahaan sampel. Dalam memperoleh data untuk penelitian ini, maka peneliti menggunakan metode dokumentasi dan studi Pustaka.

\section{Variabel Penelitian dan Pengukuran \\ Variabel Dependen}

Kualitas audit merupakan variabel dependen (Y) dalam tulisan ini. Pengukuran kualitas audit disini dengan menghitung tingkat akrual diskresioner dimana diskresioner akrual merupakan proksi untuk menilai kualitas laba. Akrual diskresioner digunakan dengan alasan bahwa akrual diskresioner memberikan indikasi adanya intervensi aktif manajemen dalam melaporkan laba (Putri \& Cahyonowati, 2014). Model kaznik 1999 digunakan untuk menghitung diskresioner akrual (Putri \& Cahyonowati, 2014). Model kaznik ini adalah cara untuk mengubah total akrual menjadi komponen diskresioner dan non diskresioner.

Untuk menghitung total akrual perusahaan digunakan rumus berikut:

Dimana:

$$
\text { TACC }_{i t}=I N C B F X T_{i t}-\text { CFO }_{i t}
$$

$\mathrm{TACC}_{\mathrm{it}}=$ Total akrual perusahaan pada periode $\mathrm{t}$

$\mathrm{INCBFXT}_{\text {it }}=$ Laba perusahaan sebelum pos-pos luar biasa pada periode $\mathrm{t}$

$\mathrm{CFO}_{\text {it }}=$ Arus kas operasi perusahaan pada periode $\mathrm{t}$

\section{Menghitung non-akrual diskresioner}

Dalam model Kasznik (1999) dipertimbangkan untuk dimasukkanya cash flow operations sebagai variabel penjelas yang tidak dipertimbangkan dalam model sebelumnya. Kasznik (1999) menyebutkan bahwa non diskresioner akrual adalah fungsi dari perubahan pendapatan yang disesuaikan dengan adanya perubahan piutang, PPE dan CFO. Persamaan model ini sebagai berikut:

$$
\begin{gathered}
\frac{T A C C_{i t}}{T A_{i t-1}}=\alpha_{i}\left(1 / T A_{i t-1}\right)+\alpha_{1}\left[\Delta R E V_{i t} / T A_{i t-1}-\Delta R E C_{i t} / T A_{i t-1}\right]+\alpha_{2}\left(P P E_{i t} / T A_{i t-1}\right) \\
+\alpha_{3}\left(-\Delta C F O_{i t} / T A_{i t-1}\right)+e_{i t}
\end{gathered}
$$

Keterangan:

TACCit/Tait-1 $=$ Total akrual perusahaan i dalam periode $\mathrm{t}$

$\triangle \mathrm{REVit}=$ Perubahan pendapatan dari tahun 1 ke tahun $\mathrm{t}(\mathrm{REVt}-\mathrm{REC} \quad \mathrm{T}-\mathrm{Q})$

$\triangle \mathrm{REC}$ it $=$ Perubahan nilai bersih piutang dai tahun 1 ke tahun $\mathrm{t}(\mathrm{RECt}-\mathrm{RECt}-1)$

PPEIT $=$ Nilai kotor aktiva tetap perusahaan $\mathrm{i}$ dalam peiode $\mathrm{t}$

$\triangle \mathrm{CFO}$ it $=$ perubahan dalam arus kas operasi dari tahun $\mathrm{t}-1$ ke tahun $\mathrm{t}$ (CFOt-CFOt-1) 


\section{Akrual diskresioner}

Akrual diskresioner dapat dihitung setelah kita memperoleh nilai total akrual perusahaan (TACC) dan nilai akrual non diskresioner (NDAC). Berikut adalah rumus untuk menghitung akrual diskresioner perusahaan:

$$
D A C C_{i t}=T A C C_{i t}-N D A C_{i t}
$$

\section{Kualitas audit}

Kualitas audit merupakan nilai negatif dari nilai akrual diskresioner.

$$
A Q=-D A C C_{i t}
$$

Variabel dummy digunakan untuk mengukur variabel kualitas audit diukur dengan maksud memisahkan perusahaan yang menyebutkan nilai tinggi rendahnya diskresioner akrual. Semakin tinggi nilai diskresioner akrual menyatakan bahwa terjadi penurunan kualtas audit karena audit yang dilakukan dianggap belum bisa mengurangi praktek manajemen laba pada perusahaan. Nilai 1 diberikan untuk kualitas audit yang baik (nilai diskresioner akrual berada di bawah angka nol) dan nilai 0 diberikan untuk kualitas audit yang buruk (nilai diskresioner akrual berada di atas angka nol).

\section{Variabel Independen}

Audit tenure pada tulisan ini didasarkan pada hasil penelitian yang telah dilaksanakan oleh Lee dan Sukartha (2017),penggunaan skala interval sesuai dengan panjangnya perikatan yang terjadi antara auditor dengan auditee yang sama. Audit tenure dihitung dari jumlah tahun perikatan auditor dengan klien audit, angka 1 untuk tahun pertama dan ditambahkan 1 untuk tahun berikutnya.

Auditor switching disini didasarkan pada penelitian yang telah dilakukan oleh Putri \& Rasmini (2016), variabel dummy digunakan untuk mengukur auditor switching, nilainya hanya 1 atau 0 . Angka 1 diberikan ketika terjadi pergantian auditor dan nilai 0 diberikan jika tidak terjadi pertukaran auditor. Untuk tahun pertama pengamatan dibutuhkan laporan keuangan tahun sebelumnya agar dapat diketahui apakah terjadi pergantian auditor atau tidak untuk tahun awal pengamatannya.

\section{Variabel Moderasi}

Untuk mengukur financial distress disini dengan menggunakan Model Altman, perseroan yang mengalami kebaangkrutan dan tidak bangkrut akan ditunjukkan oleh nilai tertentu. Altman Z-score dinyatakan dalam bentuk persamaan linear yang terdiri dari 4 hingga 5 koefisien "T" yang mewakili nilai keuangan tertentu, yakni:

$$
Z=0,71 X 1+0,874 X 2+3,107 X 3+0,420 X 4+0,99 X 5
$$

Di mana:

$\mathrm{X} 1=$ Working Capital / Total Assets

$\mathrm{X} 2=$ Retained Earnings $/$ Total Assets

X3 = Earnings Before Interest and Taxes / Total Assets

$\mathrm{X} 4=$ Book value of Equity / Total Liabilities

X5 $=$ Sales / Total Assets 
Dengan zona diskriminan sebagai berikut:

Bila $Z>2.99=$ zona "aman"

Bila $1.81<\mathrm{Z}<2.99=$ zona "abu-abu"

Bila $\mathrm{Z}<1.81=$ zona "distress"

Variabel financial distress diukur dengan memakai variabel dummy dengan maksud memisahkan perseroan yang mengalami sedang kesulitan keuangan dan perusahaan tidak menghadapi kesulitan keuangan. Apabila perusahaan klien termasuk ke dalam zona aman dan abu-abu akan diberi skor 1 dan 0 untuk perusahaan yang termasuk ke dalam zona distress.

\section{Metode Analisis Data}

Statistik Deskriptif

Statistik deskriptif memberikan gambaran atau deskripsi suatu objek yang diteliti melalui data sampel atau populasi sebagaimana adanya tanpa melakukan analisis dan kesimpulan secara umum.

\section{Analisis Regresi Logistik}

Regresi logistik yaitu regresi yang digunakan sejauh mana probabilitas terjadinya variabel dependen dapat diprediksi dengan variabel independen. Teknik analisis ini tidak memerlukan uji normalitas data pada variabel bebasnya.

\section{Pengujian Model}

Kelayakan model regresi dinilai dengan menggunakan Hosmer and Lemeshow's Goodnes of Fit Test. Jika nilai statisticHosmer and Lemeshow Goodness of fit lebih besar daripada 0,05 maka Ho tidak dapat ditolak dan berarti model mampu memprediksi nilai observasinya atau dapat dikatakan model diterima karena sesuai dengan data observasinya.

\section{Uji Keseluruhan Model}

Untuk melakukan pengujian dilakukan dengan membandingkan nilai antara -2 Log Likelihood (-2LL) pada awal (Block Number $=0$ ) dengan nilai -2 Log Likelihood (-2LL) pada akhir (Block Number $=1$ ). Jika terjadi pengurangan nilai likelihood, hal ini memberikan bukti bahwa model regresi yang digunakan telah baik atau model yang kita hipotesiskan sesuai dengan data yang didapat.

\section{Uji Koefisien Determinasi}

Koefisien determinasi digunakan untuk mengukur seberapa besar variabilitas variabel independen mampu memperjelas variabilitas variabel dependen. Koefisien determinasi pada regresi logistik dapat dilihat pada nilai Nagelkarke R Square.

\section{Matriks Klarifikasi}

Mariks klarifikasi menunjukkan kemungkinan terjadinya variabel dependen diprediksikan oleh model regresinya. Satuan persen digunakan untuk menyatakan kekuatan prediksi dari model regresi untuk memprediksi kemungkinan terjadinya variabel terikat.

\section{Uji Hipotesis}

Output dari variabel in the equation dapat memperlihatkan estimasi parameter dari model. Nilai koefisien regresi dan tingkat signifikannya ditunjukkan oleh output variable in the Equation. Koefisien regresi dari tiap variabel-variabel yang diuji menunjukkan bentuk hubungan antar variabel. 
HASIL DAN PEMBAHASAN

Statistik Deskriptif

Tabel 2

Statistic deskriptif

\begin{tabular}{llllrr} 
Variabel & N & Min & Max & Mean & \multicolumn{1}{c}{ Std. Deviasi } \\
\hline Audit Tenure (X1) & 370 & 1 & 4 & 1.67 & .72 \\
\hline Auditor Switching (X2) & 370 & 0 & 1 & .52 & .500 \\
\hline Kualitas Audit (Y) & 370 & 0 & 1 & .66 & .475 \\
\hline Financial Distress (X3) & 370 & 0 & 1 & .89 & .318 \\
\hline AT*FD & 370 & .00 & 3.00 & 1.4784 & .90516 \\
\hline AS*FD & 370 & .00 & 1.00 & .4649 & .49944 \\
\hline Valid N (listwise) & 370 & & & &
\end{tabular}

Tabel 2 merupakan tabel yang berisi statistik deskriptif setiap variabel yang diuji, hal ini berisikan nilai minimum, nilai maksimum, nilai rata-rata, dan standar deviasi. Berdasarkan tabel 2, audit tenure menunjukkan nilai minimum 1, nilai maksimum 4 dengan nilai mean 1,67 dan standar deviasi 0,782. Auditor switching memiliki nilai minimum 0 , nilai maksimum 1 dengan nilai mean 0,52 dan standar deviasi 0,500. Dari hasil analisis deskriptif pada variabel kualitas audit ditunjukkan bahwa nilai minimum 0 , nilai maksimum 1 dengan nilai mean 0,66 dan standar deviasi 0,475. Nilai mean 0,66. Dari hasil analisis deskriptif pada variabel finansial distress didapatkan nilai minimum 0 , nilai maksimum 1 dengan nilai mean 0,89 dan standar deviasi 0,318. Nilai mean 0,89 lebih besar daripada 0,50 menunjukkan bahwa sampel yang berada pada zona aman dan abu-abu lebih banyak ketimbang perusahaan yang berada pada zona distress.

\section{Hasil Uji Hipotesis Penilitian \\ Hasil Uji Keseluruhan Model (Overall Model Fit)}

Tabel 3

Hasil Uji Keseluruhan Model

\begin{tabular}{llcc}
\hline \multirow{2}{*}{ Iteration } & -2 Log likelihood & Coefficients \\
\cline { 3 - 4 } & & & Constant \\
\hline \multirow{2}{*}{ Step 0 } & 1 & 474.675 & .638 \\
\cline { 2 - 4 } & 2 & 474.631 & .661 \\
\cline { 2 - 4 } & 3 & 474.631 & .661 \\
\hline
\end{tabular}

Berdasarkan hasil pengolah data dengan menggunakan SPSS 25 pada tabel 3 menunjukkan bahwa nilai -2 Log Likelihood awal (tabel Iteration History 0) adalah sebesar 474.631. Secara matematis, nilai tersebut signifikan pada alpha 5\% yang artinya hipotesis nol (H0) ditolak. Selanjutnya dilakukan perbandingan antara nilai -2 Log Likehood awal (tabel Iteration History 0) dengan -2 Log Likehood akhir (tabel Iteration History 1). 
Tabel 4

Hasil Uji Keseluruhan Model

\begin{tabular}{|c|c|c|c|c|c|c|c|c|}
\hline \multicolumn{2}{|c|}{ Iteration } & \multirow{2}{*}{$\begin{array}{c}-2 \text { Log } \\
\text { likelihood }\end{array}$} & \multicolumn{6}{|c|}{ Coefficients } \\
\hline & & & Constant & AT & AS & FD & $\mathrm{AT}^{*} \mathrm{FD}$ & $\mathrm{AS} * \mathrm{FD}$ \\
\hline \multirow[t]{4}{*}{ Step 1} & 1 & 460.038 & -1.068 & .329 & .264 & 2.511 & -.566 & -.794 \\
\hline & 2 & 459.850 & -1.084 & .334 & .265 & 2.716 & -.623 & -.906 \\
\hline & 3 & 459.850 & -1.084 & .334 & .265 & 2.721 & -.624 & -.910 \\
\hline & 4 & 459.850 & -1.084 & .334 & .265 & 2.721 & -.624 & -.910 \\
\hline
\end{tabular}

Berdasarkan hasil output tabel 4 tersebut terjadi penurunan nilai -2 Log Likehood awal (pada saat variabel independen belum dimasukkan) sebesar 474.631 menjadi 459.850 pada nilai -2 Log Likehood akhir (pada saat variabel independen telah dimasukkan). Dapat dilihat bahwa nilai -2 Log Likehood awal lebih besar dibandingkan nilai -2 Log Likehood akhir, sehingga terjadi penurunan sebesar 14,781. Penurunan tersebut dapat diartikan bahwa penambahan variabel independen ke dalam variabel dependen ke dalam model regresi meperbaiki model fit atau dengan kata lain model fit dengan data.

\section{Hasil Uji Kelayakan Model (Hosmer and Lemeshow Test)}

\begin{tabular}{cccc}
\multicolumn{4}{c}{ Tabel 5 } \\
& \multicolumn{2}{c}{ Tabel Tes Hosmer dan Lemeshow } \\
\hline Step & Chi-square & df & Sig. \\
& & & \\
\hline 1 & .133 & 3 & .988 \\
& & & \\
\hline
\end{tabular}

Berdasarkan table 5 diatas dapat diketahui bahwa nilai signifikansi sebesar o,988. Nilai signifikansi yang diperoleh telah memenuhi syarat dengan nilai diatas $0,05(\alpha) 5 \%$ yang artinya hipotesis 0 (H0) tidak dapat ditolak atau dengan kata lain model diterima. Dengan diterimanya hipotesis nol artinya model mampu memprediksi nilai observasinya atau model dapat diterima karena sesuai dengan data yang diobservasi, sehingga model ini dapat digunakan untuk analisis selanjutnya.

\section{Hasil Uji Koefisien Determinasi (Nagelkerke R.Square)}

Uji koefisien determinasi dengan menggunakan Nagelkerke R.Square merupakan pengujian yang dilakukan guna mengetahui seberapa besar variabel independen mampu menjelaskan dan mempengaruhi variabel dependen. Nilai Nagelkerke R Square bervariasi antara 1sampai dengan 0. Jika nilai semakin mendekati 1 maka model dianggap semakin goodness of fit, sementara itu jika nilai semakin mendekati 0 maka model dianggap tidak goodness of fit (Ghozali, 2016).

\section{Tabel 6}

Tabel Model Summary

\begin{tabular}{llllll}
\hline Step & -2 Log likelihood & $\begin{array}{l}\text { Cox \& } \\
\text { Square }\end{array}$ & Snell & $\begin{array}{l}\text { Ragelkerke } \\
\text { Square }\end{array}$ & R \\
\hline 1 & $459.850^{\mathrm{a}}$ & .039 & & .054 \\
\hline
\end{tabular}

Pada table 6 diatas nilai Nagelkerke R.Square menunjukkan nilai 0,054. Hal ini berarti variabel dependen yang dapat dijelaskan oleh variabel independen dalam peneltian ini adalah 
sebesar 5,4\%. Sisanya 94,6\% dijelaskan oleh variabel independen lain di luar penlitian ini, misalnya independensi auditor, opini auditor, fee audit dan lain sebagainya. Dapat disimpulkan bahwa variasi variabel independen dalam penelitian ini yaitu audit tenure dan auditor switching mampu menjelaskan variabel dependen dalam penelitian ini yaitu kualitas audit sebesar 5,4\%.

\section{Hasil Uji Matriks Klasifikasi}

Matriks klasifikasi menunjukkan kekuatan prediksi dari model regresi guna memprediksi kemungkinan perusahaan sampel yang mempunyai kualitas audit yang baik. Kekuatan prediksi dari model regresi untuk memprediksi kemungkinan perusahaan sampel yang mempunyai kualitas audit yang baik adalah sebesar 93,4\%.

Table 7

Tabel Klasifikasi

\begin{tabular}{|c|c|c|c|c|c|}
\hline & \multicolumn{2}{|c|}{ Observed } & \multicolumn{3}{|c|}{ Predicted } \\
\hline & & & \multicolumn{2}{|c|}{$\mathrm{AQ}$} & \multirow{2}{*}{ Percentage Correct } \\
\hline & & & buruk & Baik & \\
\hline \multirow[t]{3}{*}{ Step 1} & \multirow[t]{2}{*}{$\mathrm{AQ}$} & Buruk & 25 & 101 & 19.8 \\
\hline & & Baik & 16 & 228 & 93.4 \\
\hline & \multicolumn{2}{|c|}{ Overall Percentage } & & & 68.4 \\
\hline
\end{tabular}

Pada table 7 diatas menunjukkan bahwa menurut prediksi, perusahaan yang memperoleh kualitas audit yang baik adalah 93,8\% dan 19,8\% untuk sampel yang mendapat kualitas audit yang buruk. Hal ini menunjukkan bahwa dari 370 sampel yang nilai deiskresional akrualnya mengarah pada kualitas audit yang tidak baik adalah 25 sampel, sedangkan observasi yang sesungguhnya adalah 101 sampel. Sedangkan prediksi sampel yang memperoleh kualitas audit yang bak adalah 228 sedangkan observasi sesungguhnya adalah 16 sampel, Ketepatan dari prediksi keseluruhan model ini adalah sebesar 68,4\%.

\section{Hasil Uji Signifikansi Regresi Logistik}

Pengujian hipotesis dalam penelitian ini adalah untuk menguji pengaruh variabel independen audit tenure dan auditor switching, terhadap variabel dependen kualitas audit yang memakai variabel moderasi financial distress, dengan menggunakan analisis regresi logistic yang hasilnya ditunjukkan pada table berikut.

Tabel 8

Tabel Variable in the Equation

\begin{tabular}{|c|c|c|c|c|c|c|c|}
\hline & & $\mathrm{B}$ & S.E. & Wald & $\mathrm{df}$ & Sig. & $\operatorname{Exp}(B)$ \\
\hline \multirow{6}{*}{ Step $1^{a}$} & AT & .334 & .766 & .190 & 1 & .663 & 1.396 \\
\hline & $\mathrm{AS}$ & .265 & 1.238 & .046 & 1 & .831 & 1.303 \\
\hline & FD & 2.721 & 2.085 & 1.704 & 1 & .192 & 15.197 \\
\hline & $\mathrm{AT} * \mathrm{FD}$ & -.624 & .846 & .544 & 1 & .461 & .536 \\
\hline & AS*FD & -.910 & 1.362 & .446 & 1 & .504 & .403 \\
\hline & Constant & -1.084 & 1.884 & .331 & 1 & .565 & .338 \\
\hline
\end{tabular}

Berdasarkan table diatas maka model regresi yang terbentuk adalah sebagai berikut:

$$
\begin{aligned}
& \text { Ln } \frac{p \text { (kwalitas) }}{1-p \text { (kwalitas }}=-1.084+0.334 \text { Tenure }+0.265 \text { Switch }+ \\
& 2.2721 \text { LnFD }-0.624 \text { Tenure } * \text { LnFD }-0.910 \text { Switch } * \text { LnFD }+\varepsilon
\end{aligned}
$$


H1: Audit tenure memiliki pengaruh negatif terhadap kualitas audit. Hasil pengujian menunjukkan bahwa variabel audit tenure memiliki koefisien sebesar 0,334 dengan tingkat signifikansi sebesar 0,663 yang artinya lebih besar dari 0,05, sehingga Ha1 ditolak.

H2: Auditor switching memiliki pengaruh positif terhadap kualitas audit. Hasil pengujian menunjukkan bahwa variabel auditor switching memiliki koefisien sebesar 0,265 dengan tingkat signifikansi sebesar 0,831 yang artinya lebih besar dari 0,05, sehingga Ha2 ditolak.

H3: Financial distress memperkuat hubungan audit tenur terhadap kualitas audit. Hasil pengujian menunjukkan bahwa variabel audit tenure memiliki koefisien sebesar $-0,624$ dengan tingkat signifikansi sebesar 0,831 yang artinya lebih besar dari 0,05, sehingga Ha3 ditolak.

H4: Financial distress memperlemah hubungan auditor switching terhadap kualitas audit. Hasil pengujian menunjukkan bahwa variabel auditor switching memiliki koefisien sebesar 0,910 dengan tingkat signifikansi sebesar 0,504 yang artinya lebih besar dari 0,05, sehingga

Ha4 ditolak.

\section{PEMBAHASAN}

\section{Pengaruh Audit Tenure (AT) terhadap Kualitas Audit (AQ)}

Dari pengamatan yang dilakukan didapati bahwa hipotesis pertama audit tenure tidak berpengaruh terhadap kualitas audit. Hasil yang didapat sesuai dengan hasil penelitian Herianti \& Suryani (2016) bahwa audit tenure tidak berpengaruh terhadap kualitas audit. Hal ini terjadi karena tidak selamanya tenure audit yang panjang selalu mempengaruhi independensi auditor sehingga dapat menurunkan kualitas audit, sebaliknya audit tenure yang pendek juga tidak menjamin keandalan kualitas audit yang disebabkan karena terdapat kemungkinan auditor belum memiliki pemahaman yang memadai tentang kegiatan bisnis klien. Hal ini mengakibatkan tidak terdapat pengaruh antara audit tenure dengan kualitas audit.

Dalam teori kegenan hubungan principal dengan agen berada dalam hubungan keagenan, begitu pula dengan hubungan manajemen dengan auditor yang memiliki hubungan kelembagaan. Hubungan ini dilandasi dengan adanya kontrak. Kontrak tersebut mengenai jasa yang diberikan oleh auditor kepada manajemen untuk tujuan pemeriksaan laporan keuangan perusahaan. Dalam pelaksanaannya, auditor yang ditunjuk oleh perusahaan dalam jangka waktu yang panjang akan lebih mengenal seluk beluk perusahaan sehingga panjangnya audit tenure atau perikatan audit tidak akan membuat penurunan tehadap kualitas audit.

Hasil ini tidak sesuai dengan penelitian yang dilakukan oleh Ball, et al., (2015) bahwa audit tenure mengurangi kualitas audit. Hal ini terjadi karena hubungan mitra audit yang lebih lama dengan manajemen senior dapat mengurangi kualitas audit melalui penurunan independensi audit, sehingga manajemen dapat mengadopsi kebijakan akuntansi yang lebih liberal.

\section{Pengaruh Auditor Switching (AS) terhadap Kualitas Audit (AQ)}

Dari pengamatan yang dilakukan didapati bahwa hipotesis kedua, auditor switching tidak berpengaruh terhadap kualitas audit. Hasil penelitian ini sesuai dengan hasil penelitian Muliawan \& Sujana, (2017), bahwa auditor switching tidak berpengaruh pada kualitas audit. Baik atau buruknya kualitas audit tidak dipengaruhi oleh dengan adanya pergantian auditor. Hal ini terjadi karena independensi auditor tidak mengalami penurunan ketika terjadi pergantian auditor, sehingga kualitas audit tetap terjaga. Selain itu lamanya kontrak yang terjadi antara klien dengan auditor yang sama (audit tenure) tidak mempengaruhi kualitas audit. 
Hasil penelitian ini menunjukkan dengan adanya pergantian auditor tidak dapat bisa mepengaruhi kualitas audit. Dari hasil observasi yang dilakukan dari 370 pengamatan sebanyak $52 \%$ perusahaan melakukan pergantian auditor secara rutin, namun hal ini tidak dapat mempengaruhi kualitas audit. Hal ini terjadi karena dengan dilakukannya pergantian auditor tidak dapat menajamin independensi auditor juga akan berubah, dengan hasil ini juga mendukung peraturan pemerintah tahun 2015 mengenai pergantian auditor dapat dilakukan dalam 5 tahun perikatan auditor dengan perusahaan yang sama.

Hasil penelitian ini berbeda dengan hasil penlitian yang dilakukan oleh Jayanti \& Widhiyani (2014) bahwa auditor switching memiliki pengaruh positif terhadap kualitas audit, artinya dengan melakukan pergantian auditor akan menjaga independensi auditor karena hubungan auditor dengan klien tetap terjaga, sehingga kualitas audit dapat meningkat.

\section{Pengaruh Financial distress (FD) dalam Memoderasi Audit Tenure (AT) terhadap Kualitas Audit (AQ)}

Dari pengamatan yang dilakukan didapati bahwa hipotesis ketiga, financial distress tidak mampu memoderasi hubungan antara audit tenure terhadap kualitas audit. Financial distress dalam penelitian ini diukur dengan menggunakan Altman Z score, perusahaan yang berada pada zona aman dan abu-abu akan diberi score 1 dan sore 0 diberikan untuk perusahaan yang termasuk kedalam zona distress.

Hasil penelitian ini sesuai dengan penelitian yang dilakukan oleh Wulandari \& Wiratmaja (2017), financial distress tidak mampu memoderasi pengaruh audit tenure. Hal ini terjadi karena tidak selamanya perusahaan yang mengalami kondisi kesulitan keuangan akan mencari auditor pengganti, sebaliknya financial distress akan membuat perusahaan tetap mempertahankan auditornya agar tidak terjadi penambahan biaya ketika perusahaan memutuskan untuk mengganti auditornya, sehingga tenure audit yang terjadi akan menjadi semakin panjang. Selain itu dengan mempertahankan auditor perusahaa dapat meminta saran dari auditor agar dapat keluar dari kondisi kesulitan.

Dari hasil pengamatan pada 370 sampel didapati nilai financial distress sebanyak $89 \%$ tidak mengalami kondisis kesulitan keuangan dan juga berada pada area abu-abu, sisanya sebanyak 11\% mengalami kondisi kesulitan keuangan. Minimnya perusahaan yang mengalami kondisi kesulitan keuangan tidak mempengaruhi perusahaan untuk melakukan pergantian auditor, dimana dari rata-rata yang didapat perusahan hanya mempertahankan auditornya selama 1,67 tahun.

Hasil penelitian ini berbeda dengan penelitian yang dilakukan oleh Pradnyaniti \& Suardikha (2019), yang menemukan bahwa financial distress mampu memperlemah pengaruh audit tenure, artinya dengan perusahaan mengalami kondisi kesulitan keuangan akan membuat audit tenure menjadi semakin panjang. Hal ini terjadi karena karena perusahaan yang mengalami kondisi kegagalan keuangan akan memerlukan saran-saran perbaikan dari auditor yang melakukan audit sebelumnya agar dapat keluar dari kondisi kesulitan keuangan, sehingga audit tenure menjadi semakin panjang.

\section{Pengaruh Financial distress (FD) dalam Memoderasi Auditor Switching (AS) terhadap Kualitas Audit (AQ)}

Dari pengamatan yang dilakukan didapati bahwa hipotesis keempat yang menunjukkan bahwa variabel auditor switching memiliki koefisien sebesar -0,910 dengan tingkat signifikansi sebesar 0,504 yang artinya lebih besar dari 0,05. Hasil analisis regresi tersebut menunjukkan bahwa variabel financial distress tidak mampu memoderasi hubungan auditor switching dengan kualitas audit, dengan demikian Ha4 tidak berhasil didukung, atau Ha4 ditolak. 
Hasil penelitian ini sesuai dengan penelitian yang dilakukan oleh Pradnyaniti \& Suardikha (2019), bahwa financial distress tidak mampu memoderasi hubungan auditor switching. Hal ini terjadi karena perusahaan yang mengalami kondisi kegagalan keuangan akan memerlukan saran-saran perbaikan dari auditor yang melakukan audit agar dapat keluar dari kondisi kesulitan keuangan ini, sehingga perlu mempertahankan auditor sebelumnya.

Dari hasil pengamatan pada 370 sampel didapati nilai financial distress sebanyak $89 \%$ tidak mengalami kondisis kesulitan keuangan dan juga berada pada area abu-abu, sisanya sebanyak 11\% mengalami kondisi kesulitan keuangan. Minimnya perusahaan yang mengalami kondisi kesulitan keuangan tidak mempengaruhi perusahaan untuk melakukan pergantian auditor, dimana dari pengamatan yang dilakukan sebanyak 52\% melakukan pergantian auditor.

Hasil penelitian ini berbeda dengan penelitian yang dilakukan Jayanti \& Widhiyani (2014), yang menemukan bahwa financial distress mampu memoderasi hubungan auditor switching dengan kualitas audit. Hal ini dapat terjadi karena perusahaan yang mengalami kondisi kesulitan keuangan mendorong perusahaan untuk mencari auditor pengganti dengan biaya audit yang lebih rendah, akan tetapi memiliki pemahaman yang lebih rendah dari auditor sebelumnya, sehingga dapat menrunkan kualitas audit.

\section{SIMPULAN, KETERBATASAN DAN SARAN \\ Simpulan}

Tulisan ini bertujuan untuk mendapat bukti empiris tentang bagaimana kualitas audit dipengaruhi oleh audit tenure, auditor switching dan financial distress sebagai pemoderasi pada perusahaan sector manufaktur yang terdapat di BEI pada tahun 2015-2019. Berdasarkan hasil temuan dapat disimpulkan bahwa hoipotesis pertama ditolak, artinya tidak terdapat pengaruh audit tenure terhadap kualitas audit. hipotesis kedua ditolak, artinya tidak terdapat pengaruh auditor switching terhadap kualitas audit. Hipotesis ketiga dan keempat ditolak, artinya variabel financial distress tidak bisa mempengaruhi hubungan audit tenure dan auditor switching pada kualitas audit.

\section{Keterbatasan}

Tulisan ini memiliki beberapa keterbatasan yang bisa mempengaruhi hasil temuan. Beberapa keterbatasan dalam tulisan ini adalah sebagai berikut:

1. Penelitian ini hanya dilakukan pada perusahaan sector manufaktur yang terdaftar di BEI dan dilakukan hanya pada periode 2015-2019, sehingga belum mewakilkan seluruh perusahaan di Indonesia.

2. Penelitian ini terbatas pada literasi financial distress sebagai variabel moderasi, dimana masih sedikit penelitian yang penulis temui yang membahas masalah ini.

3. Terbatasnya pengukuran variabel kualitas audit, auditor switching dan financial distress pada pengukuran variabel dummynya.

\section{Saran}

Saran penulis terkait dengan variabel penelitian serupa di masa yang akan datang, supaya bisa menyajikan hasil yang lebih berkualitas, berikut beberapa masukan bagi penelitian selanjutnya:

1. Penelitian selanjutnya disarankan agar pengukuran audit tenure tidak hanya dihitung dengan menghitung tahun auditor melakukan audit pada perusahaan yang sama pada tahun pengamatan, tetapi juga dimasukkan tahun-tahun sebelumnya.

2. Penelitian selanjutnya yang menggunakan variabel financial distress agar memisahkan perusahaan yang berada pada area abu-abu, tidak dimasukkan lagi kedalam zona aman atau zona distress. 
3. Penelitian selanjutnya disarankan agar menambah sampel dan tahu penelitian, tidak lagi terbatas pada satu sektor.

4. Penelitian selanjutnya disarankan agar menambahkan variabel-variabel yang memiliki hubungan yang lebih kuat terhadap kualtas audit, seperti audit delay dan independensi auditor.

\section{DAFTAR PUSTAKA}

Aisyah, F., Gunawan, H. \& Purnamasari, P. (2015). Pengaruh Audit Rotation dan Audit Tenure terhadap Kualitas Audit dengan Fee Audit sebagai Variabel Pemoderasi (Studi pada Perusahaan Manufaktur yang Terdaftar di BEI Tahun 2012-2014). Jurnal Akuntansi. Bandung.

Anggara, M. A. (2017). Pengaruh Etika Profesi, Pengalaman, Pengetahuan dan Gender Terhadap Pertimbangan Tingkat Materialitas (Studi Empiris pada KAP Padang Dan Pekanbaru). Jurnal Akuntansi. Riau., 4(1), pp. 739-751.

DeAngelo, L. E. (1981). Auditor Size and Audit Quality. Journal of Accounting and Economics, pp. 183-199.

Ghozali, I. (2016). Aplikasi Analisis Multivariete Dengan Program IBM SPSS 23 (Edisi 8). Cetakan ke VIII. 8 penyunt. Semarang: Badan Penerbit Universitas Diponegoro.

Herianti, E. \& Suryani, A. (2016). Pengaruh Kualitas Auditor, Audit Delay dan Audit Tenure Terhadap Kualitas Audit Perbankan yang Terdaftar di BEI Periode 2012-2014. Jurnal Akuntansi, Jakarta., pp. 416-425.

Kurniasih, M. \& Rohman, A. (2014). Pengaruh Fee Audit, Audit Tenure, Dan Rotasi Audit Terhadap Kualitas Audit. DIPONEGORO JOURNAL OF ACCOUNTING, 3(3), pp. 110.

Lee, D. \& Sukartha, I. M. (2017). Fee Audit Sebagai Pemoderasi Pengaruh Auditor Switching dan Audit Tenure Pada Kualitas Audit. E-Jurnal Akuntansi Universitas Udayana, 18(2), pp. 1455-1484.

Lestari, D. I., Maryani, N. \& Lestari, A. (2019). Pengaruh Due Professional Care dan Kompetensi Auditor Terhadap Kualitas Audit. JURNAL RISET AKUNTANSI DAN KEUANGAN, 7(2), pp. 319-326.

Pradnyaniti, L. P. Y. \& Suardikha, I. M. S. (2019). Pengaruh Audit Tenure dan Auditor Switching Pada Audit Delay Dengan inancial Distress Sebagai Variabel Pemoderasi. EJurnal Akuntansi Universitas Udayana, Volume 26, pp. 2098-2122.

Putri, T. M. \& Cahyonowati, N. (2014). Pengaruh Auditor Tenure, Ukuran Kantor Akuntan Publik, Dan Ukuran Perusahaan Klien Terhadap Kualitas Audit. Diponegoro Journal Of Accounting , 3(2), pp. 1-11.

Tandiontong, M. (2015). Kualitas Audit dan Pengukurannya. Bandung: Penerbit Alfabeta.

Werastuti, D. N. S. (2013). Pengaruh Auditor Client Tenure, Debt Default, Reputasi Auditor, Ukuran Klien dan Kondisi Keuangan Terhadap Kualitas Audit Melalui Opini Audit Going Concern. VOKASI Jurnal Riset Akuntansi, 2(1), pp. 99-116.

Wibowo, A. \& Rossieta, H. (2009). Faktor-Faktor Determinasi Kualitas Audit Suatu Studi Dengan Pendekatan Earnings Surprise Benchmark. Simposium Nasional Akuntansi.

Wisanggeni, A. A. \& Ghozali, I. (2017). Pengaruh Auditor Relationships Terhadap Kualitas Audit Pada Perusahaan Manufaktur Di Indonesia (Studi Empiris Pada Perusahaan Manufaktur Yang Terdaftar Pada Bursa Efek Indonesia Tahun 2011). DIPONEGORO JOURNAL OF ACCOUNTING, 6(1), pp. 1-14. 